\title{
都市流域の不浸透流出面（屋根面，道路面） における雨水・污濁負荷流出特性 \\ RUNOFF CHARACTERISTICS OF STORMWATER AND WASHOFF WATER QUALITY FROM ROOF AND ROAD SURFACES
}

\author{
渡辺 政広 1 ・西村 文武 $2 \cdot$ 重田 尚秀 $3 \cdot$ 小林 康司 4 \\ Masahiro WATANABE, Fumitake NISHIMURA, Naohide SHIGETA and Yasushi KOBAYASHI \\ 1 正会員 工博 愛媛大学助教授 工学部環境建設工学科（广790-8577 愛媛県松山市文京町 3 番） \\ 2 正会員 工博 愛媛大学講師 工学部環境建設工学科 (同上) \\ 3 学生会員 愛媛大学大学院理工学研究科 環境建設工学専攻 (同上) \\ 4 学生会員 愛媛大学大学院理工学研究科 土木海洋工学専攻（同上）
}

\begin{abstract}
Owing to overflows from combined sewer pipe systems, water quality of receiving waters, including urban rivers, has become worse year by year. Appropriate countermeasures that can mitigate the overflows, therefore, must be developed promptly. The authors have investigated a distributed simulation model of water quality and stormwater runoff in urban sewer pipe systems. First, a surface routing model of stormwater and pollutants, which is a sub-model of the distributed model, is proposed. Second, the routing model is applied to a roof and a road surface of Matsuyama city and the applicability of the model is investigated on the basis of the comparisons of observed and simulated hydrographs.
\end{abstract}

Key Words : Road and roof surfaces, washoff equation, water quality, distributed runoff model, urban sewer pipe systems

\section{1. はじめに}

近年，都市域の合流式下水道管渠システムからの雨 天時越流水による公共用水域の水質の悪化が問題とな ってきている.

このような問題を解決するためには，先ず，都市域 における各種流出面上と下水道管渠システム内におけ る雨水と污濁負荷の非定常で不均一な流出を解析しえ る計算モデル，すなわち，図-1に示すような，雨水と 污濁負荷の分布型非定常流出解析モデルが必要となる.

本論文では，上述の流出解析モデルの開発を目指し た研究の一環として, 市街地の屋根面・道路面におけ る雨水・污濁負荷流出の観測を行い，既に提案されて いる流出面における雨水・污濁負荷流出の基礎式（流 出面における雨水・污濁負荷の流出モデル，図-1）の 適用性について検討した.

\section{2. 雨水・污濁負荷流出の観測}

\section{(1）屋根面 ${ }^{1)}$}

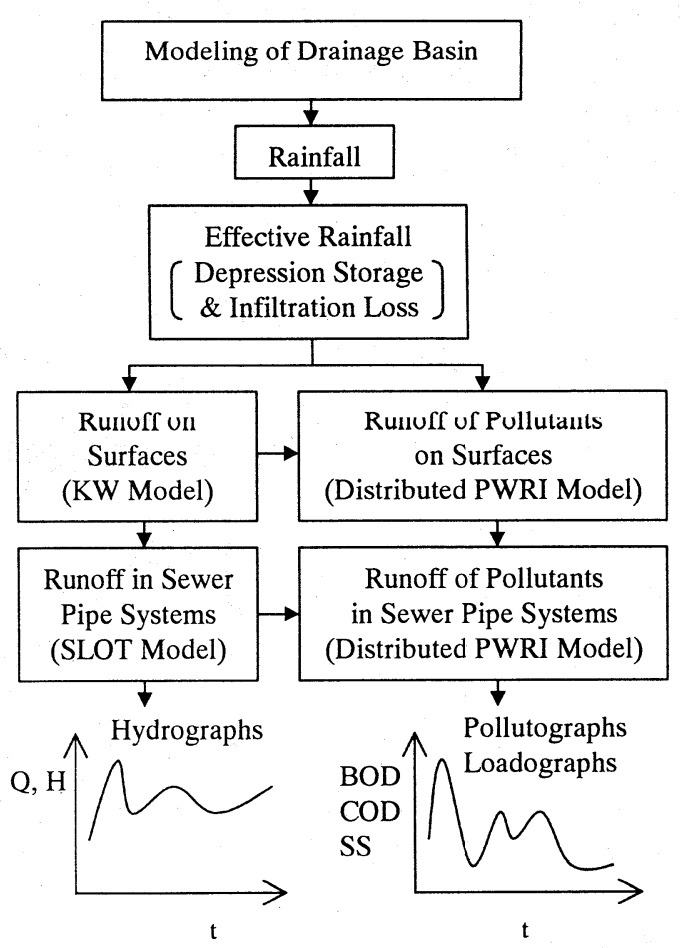

図-1 雨水・污濁負荷流出の分布型非定常解析モデル. 


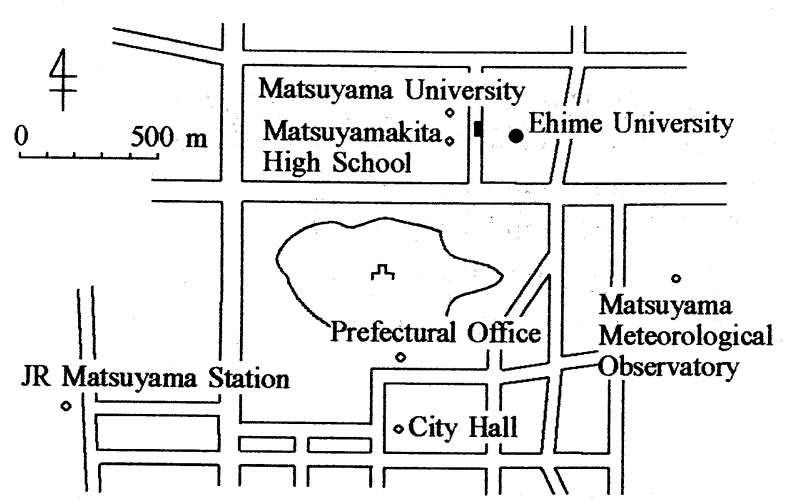

図-2 観測解析対象流出面の位置図.

表-1 交通量調查結果

\begin{tabular}{|c|r|r|}
\hline Date & $\begin{array}{l}\text { Nov. 17, } \\
1999\end{array}$ & $\begin{array}{l}\text { Nov. 28, } \\
1999\end{array}$ \\
\hline Motorcycle & 539 & 184 \\
\hline Automobile & 1058 & 609 \\
\hline Truck and Bus & 34 & 2 \\
\hline Total & 1631 & 795 \\
\hline
\end{tabular}

愛媛大学（松山市文京町 3 番, 図-2) 構内の水理実 験室の屋根面を調査・解析対象の流出面に選び, 雨水 と污濁負荷の流出観測を行った.

屋根面の概要を，図-3（a）に示す．雨水および污濁 負荷の流出の観測は, 屋根と雨水マスを結ぶ 7 本の鈶 直パイプの中の 1 本の経路を, 図-3（a）に示すように, 塩化ビニール製のパイプに変え, 実験室内に引き込ん で行った. 屋根面の観測対象部分の集水（排水）面積 は $73 \mathrm{~m}^{2}$, 樋に向かう屋根面上の流れの勾配は $19 \%$. 樋のそれは $6.0 \%$ \%である.

解析の対象とした水質項目は, 濁度, T-CODである. 水質の計測は, 濁度には水質チェッカーU-10（堀場製 作所）を, COD にはCOD 計（笠原理化工学株式会社） および共立 COD パックテスト (共立理化学研究所) を 用いて行った.

降雨デー夕には, 愛媛大学より直線距離で約 $700 \mathrm{~m}$ 離れた松山地方気象台（図-2）で観測された地上観測 原簿 $(0.5 \mathrm{~mm}$ 転倒マス雨量計記録および 1 分間降雨強 度計記録)を用いた。

降雨・流出・水質の観測は, 平成 8 年（1996 年） 6 月 12 日から同年 11 月 9 日までの約 5 ケ月間の計 22 の 降雨・流出に対して行われた.

\section{(2) 道路面 ${ }^{2)}$}

愛媛大学と隣接する松山北高校との間を南北に走る 道路面（図-2）を調査・解析対象の流出面に選び，雨

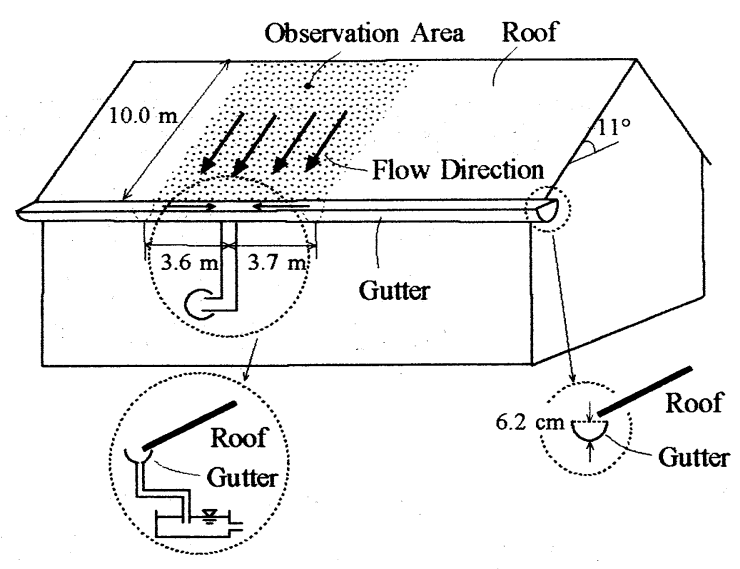

(a) 屋根面

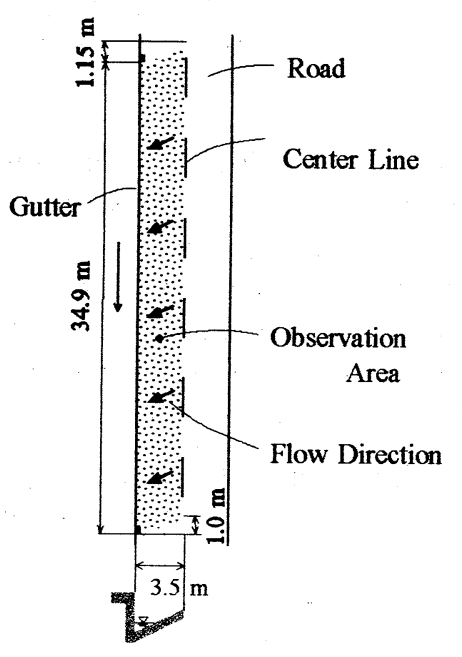

(b) 道路面

図-3 観測・調査・解析対象流出面.

水と污濁負荷の流出観測を行った.

道路面は，図-3（b）に示すように，ほぼ平行四辺形 状をしており，集水（排水）面積は $123 \mathrm{~m}^{2}$, 側溝に向 かう道路面上の流れの勾配は $29 \%$, 側溝のそれは $5.8 \%$ \%゙ある.

雨水および污濁負荷の流出の観測は，集水域の下流 端にある雨水マスで行った. 解析の対象とした水質項 目は, SS, D-COD，T-COD で, それらの濃度は下水試 験方法 ${ }^{3)}$ に従って測定した. 降雨デー夕には, 道路面 の傍に設置された受水マス（直径 $20 \mathrm{~cm}$ ）で集水された 降雨量を 5 分間隔で測定して得られた 5 分間強度記録 を用いた。

降雨・流出・水質の観測は，平成 11 年（1999 年） 6 月 23 日から同年 11 月 12 日までの約 5 ケ月間の計 $9 \supset$ の降雨・流出に対して行われた.

なお, 本道路面に対し, 平日 (平成 11 年 11 月 17 日・ 水曜日・ 7 a.m. 7 p.m.) および日曜日（平成 11 年 11 月 28 日・7 a.m.〜 7 p.m.）に実施された 2 回の交通量調 
表-2 都市下水道流域における代表流出面

\begin{tabular}{|c|c|c|}
\hline $\begin{array}{c}\text { Surface Flow } \\
\text { Planes }\end{array}$ & $\begin{array}{l}\text { Pervious / } \\
\text { Impervious }\end{array}$ & Rainfall Loss \\
\hline Steep Slope & \multirow{3}{*}{ Impervious } & None \\
\hline Flat Slope & & \multirow{2}{*}{$\begin{array}{c}\text { Depression } \\
\text { Storage }\end{array}$} \\
\hline $\begin{array}{c}\text { Road and } \\
\text { Parking Lot }\end{array}$ & & \\
\hline Small Bare Land & \multirow{2}{*}{ Pervious } & \multirow{2}{*}{$\begin{array}{l}\text { Depression } \\
\text { Storage } \\
\text { Infiltration }\end{array}$} \\
\hline Large Bare Land & & \\
\hline
\end{tabular}

査結果を，表-1 に示しておく.

\section{3. 雨水・污濁負荷流出モデルとその適用性}

\section{（1）雨水流出モデルとその適用性 2}

\section{a) 雨水損失の算定}

市街地の流出面を，表-2に示すように分類する．屋 根面之道路面における凹地損失は， Linsley らの指数関 数型の近似式 ${ }^{4)}$ を適用すると, 次のように表される.

$$
D_{S}=S_{d}\left\{1-\exp \left(-P_{e} / S_{d}\right)\right\}
$$

ここに, $D_{s}$ : 累加凹地貯留量, $S_{d}$ : 最大凹地貯留量, $P_{e}:$ 累加余剩降雨量, である.

\section{b）雨水流出の追跡}

屋根面, 樋および道路面, 側溝の流れは, いずれも, kinematic wave 流れとして取り扱う. 流れの運動方程式 および連続の式は，次式のように表される.

屋根 $\cdot$ 道路面 $: h=k^{\prime} \cdot q^{p}, \frac{\partial h}{\partial t}+\frac{\partial q}{\partial x}=r_{e}$

樋 $\cdot$ 側溝 : $F=K \cdot Q^{P}, \frac{\partial F}{\partial t}+\frac{\partial Q}{\partial x}=q$

ここに, $h$ : 水深, $q$ : 単位幅流量, $r_{e}$ : 有効降雨強度, $k^{\prime}, p$ : 斜面定数, $F$ : 流水断面積, $Q$ : 流量, $K, P$ : 水路定数, $x:$ 距離, $t:$ 時間, である.

\section{c）モデルの適用性}

上述の雨水流出モデルを, 調査・解析対象の屋根面 および道路面に適用し，雨水流出シミュレーション結 果を実測結果と対比して, 本モデルの適用性（適合性） を検討した．検討の一例を，図-4に示す.

これらより，本モデルの適合性がかなり高いもので あることがわかる.

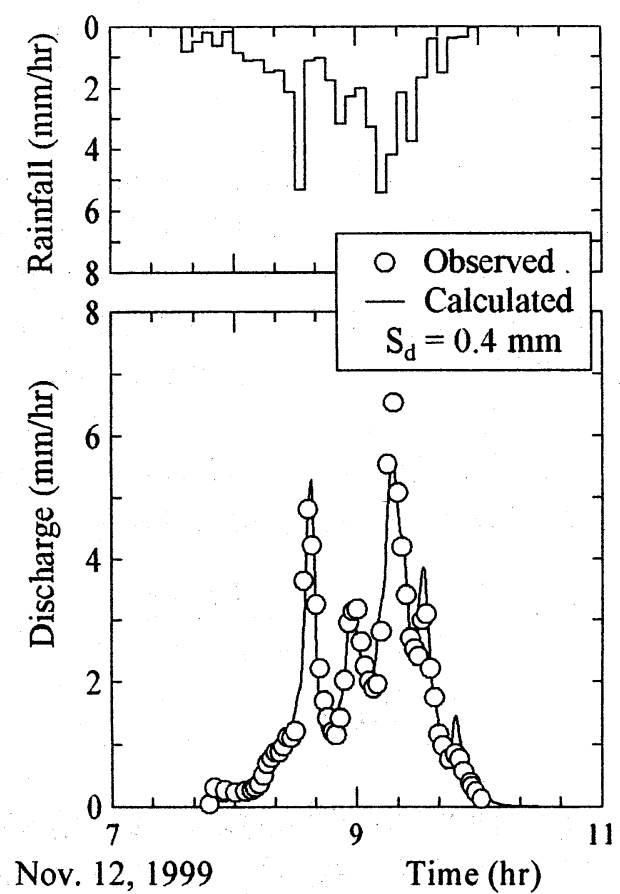

図-4 雨水流出シミュレーション結果（道路面).

（2）污濁負荷流出モデルとその適用性

a）污濁負荷流出の基礎式 5)，6)

はじめに，屋根面・道路面に堆積した污濁物質の降 雨による流出は, 次式のように表される.

$$
L_{S}=\alpha_{L} k P_{S} r_{e}^{b} A
$$

ここに, $L_{s}$ : 污濁負荷流出量 $(\mathrm{mg} / \mathrm{sec}), P_{S}$ : 流出面 上の残存污濁負荷量 $\left(\mathrm{mg} / \mathrm{m}^{2}\right), r_{e}$ : 有効降雨強度 $(\mathrm{mm} / \mathrm{hr}), b$ : べき指数 $(b \geqq 1), k$ : 污濁負荷流出係数 $(1 / \mathrm{mm}), \alpha_{L}$ : 污濁負荷流出量についての単位換算係数 $=1 / 3600(\mathrm{~mm} / \mathrm{hr})^{1-b}, A$ : 排水 (集水) 面積 $\left(\mathrm{m}^{2}\right)$, であ る.

次に, 降雨流出期間中の污濁の堆積を無視すると, $P_{S}$ に関する連続の式は, 次のように表される.

$$
d P_{S} / d t=-L_{S} / A
$$

\section{b）污濁負荷の流出特性 ${ }^{6)}$}

はじめに，式(4)を式(5)に代入し，これを，降雨開始 時刻 $t=0$ から任意時刻 $t=t$ の間で積分すると, 残存污 濁負荷量 $P_{s}$ に関する式(6)および累加流出污濁負荷量 $\left(P_{S 0}-P_{S}\right)$ に関する式(7)が得られる.

$$
\begin{gathered}
P_{S}=P_{S 0} \exp \left(-\alpha_{L} k \int_{0}^{t} r_{e}^{b} d t\right) \\
\int_{0}^{t} L_{S} d t=P_{S 0}-P_{S}
\end{gathered}
$$




$$
=P_{S 0}\left\{1-\exp \left(-\alpha_{L} k \int_{0}^{t} r_{e}^{b} d t\right)\right\}
$$

ここに, $P_{s 0}$ : 初期堆積污濁負荷量 $\left(\mathrm{mg} / \mathrm{m}^{2}\right)$, である.

式(6)は, 残存污濁負荷量は累加降雨量の増加と共に 指数関数的に減少してゆくことを示している. また, 式(7)は, 累加流出污濁負荷量 $\left(P_{s 0}-P_{S}\right)$ は累加降雨量 の増加と共に指数関数的に増大し, やがて, $P_{s 0}$ に漸 近することを示している.

次に, 污濁負荷の流出濃度 $C_{s}$ は污濁負荷流出量 $L_{S}$ と雨水流出流量 $Q_{s}$ から, 式(8)のように表される.

$$
\begin{aligned}
C_{S}= & \alpha_{C} \frac{L_{S}}{Q_{S}}=\alpha_{C} \frac{\alpha_{L} k P_{S} r_{e}^{b} A}{\alpha_{Q} r_{e} A} \\
= & \frac{\alpha_{C} \alpha_{L}}{\alpha_{Q}} k P_{S} r_{e}^{b-1}
\end{aligned}
$$

ここに, $Q_{s}$ : 雨水流出流量 $\left(\mathrm{m}^{3} / \mathrm{sec}\right), \alpha_{Q}$ : 雨水流出 流量についての単位換算俰数, $C_{s}$ : 污濁負荷流出濃度 $(\mathrm{mg} /), \alpha_{C}$ : 污濁負荷流出濃度についての単位換算係 数, である.

ここで, $b=1$ の場合, 污濁負荷流出濃度 $C_{S}$ は, 式 (8)より, 次式のように表される.

$$
C_{S}=\frac{\alpha_{C} \alpha_{L}}{\alpha_{Q}} k P_{S}
$$

式(8)および式(9)より, 降雨期間中における $P_{S}$ は常 に減少しているので, $b=1$ の場合, 降雨期間中, $C_{s}$ は 常に減少し続けること，一方， $b>1$ の場合（たとえ ば, $b=2$ の場合), $C_{S}$ は降雨強度の強弱に応じて増減 することが分かる.

\section{c）モデルの適用性 ${ }^{6)}$}

はじめに, 式(7)で表される累加降雨量と累加流出污 濁負荷量の関係について, 屋根面では T-COD および濁 度 (Turbidity) を対象に, 道路面ではT-COD およびSS を対象に検討した．検討結果の一例を，図-5 および図 -6 に示す.

これらより，屋根面および道路面のいずれにおいて も，また，いずれの水質項目についても，観測された 累加降雨量と累加流出污濁負荷量のグラフには, 累加 降雨量の増大と共に指数関数的に増加し, 累加降雨量 が屋根面では $0.3 \mathrm{~mm}$ を, 道路面では $3 \mathrm{~mm}$ を過ぎるあ たりから $P_{S 0}$ に漸近してゆく傾向, すなわち, 式(7)が 述べている污濁負荷の流出特性がよく反映されている ことが分かる.

次に，式(8)および式(9)で表される污濁負荷流出濃度 と有効降雨強度との関係について, 上と同様に検討し た. 検討結果の一例を, 図-7 および図-8 に示す.

これらより，屋根面および道路面のいずれにおいて
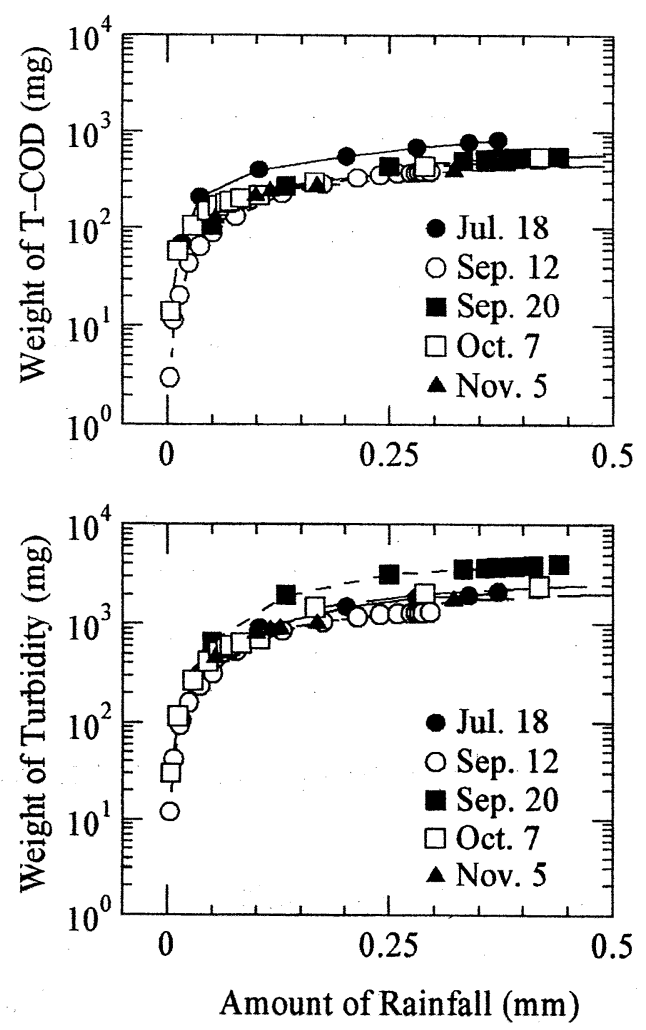

図-5 累加降雨量と累加污濁流出量の関係 (屋根面).
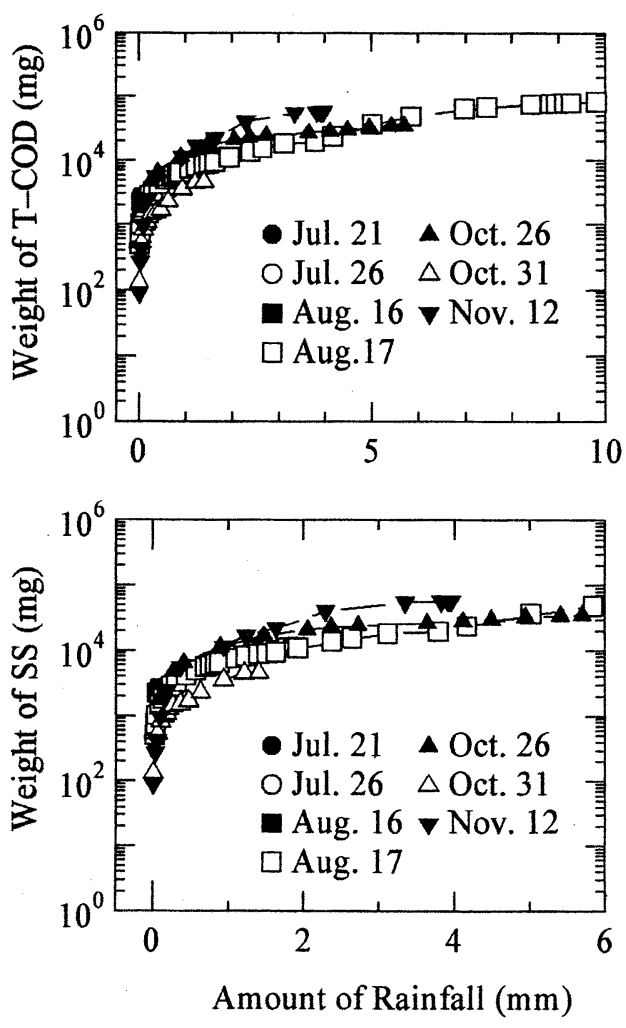

図-6 累加降雨量と累加污濁流出量の関係 (道路面). 

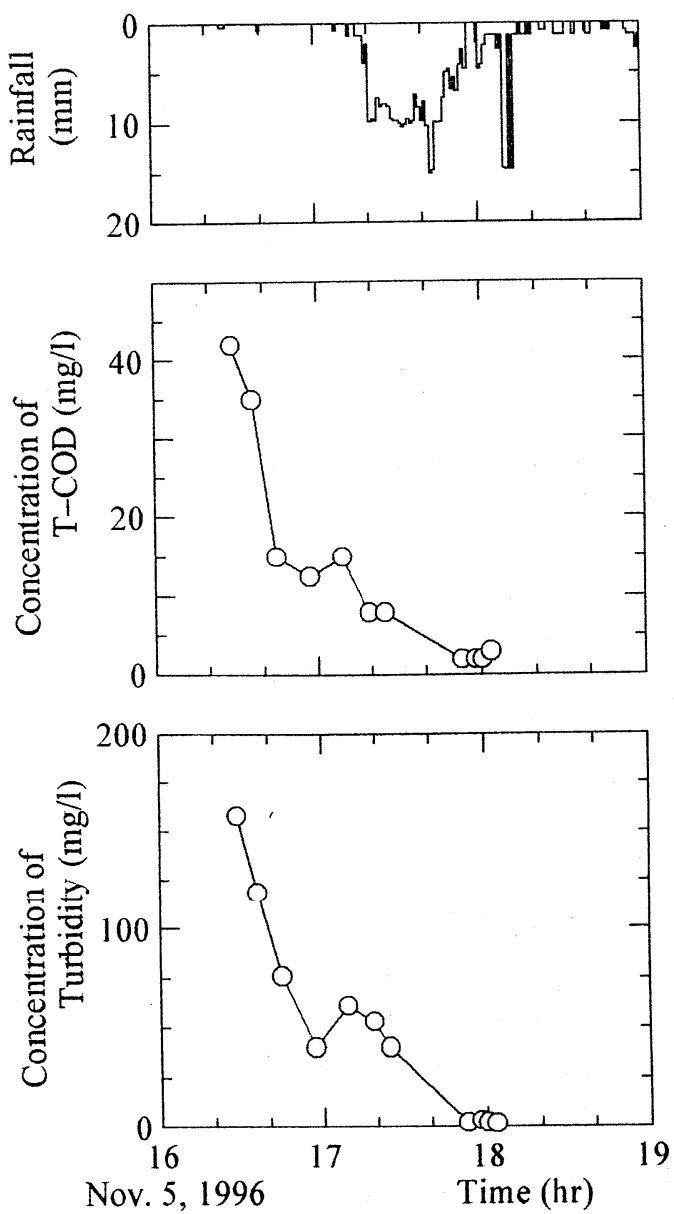

図-7 観測されたポリュート・グラフ (屋根面).

も，観測されたポリュート・グラフには，溶解性の污 濁が主体を占める T-COD，D-COD では降雨期間中ほ ぼ减少し続けているので $b=1$, 固形性（粒子性）の污 濁が主体を占める濁度, SS では降雨強度の強弱に応じ て増減しているので $b>1$ (たとえば, $b=2)$ である ベきこと，すなわち，式(8)および式(9)が述べている污 濁負荷の流出特性がよく反映されていることが分かる.

以上より，屋根面および道路面からの污濁負荷の流 出は，式(4)および式(5)を用いて精度よく解析できるで あろうことが分かる.

d）污濁負荷流出係数の適值および前期無降雨日数と 初期堆積污濁負荷量の関係

上述した流出面における污濁負荷流出モデル（式(4) および式(5)）を実流域に適用するに当たり，モデル・ パラメータ $k$ および初期堆積污濁負荷量 $P_{s 0}$ がどの程 度の值をとるかを明らかにしておく必要がある.

ここでは, 道路面で観測した 7 つの降雨・流出を選 び, D-COD およびSS を対象として, $k$ および $P s_{s}$ の 組合せを種々に変え, 式(4)および式(5)による污濁負荷 流出シミュレーションを行い, シミュレーション結果
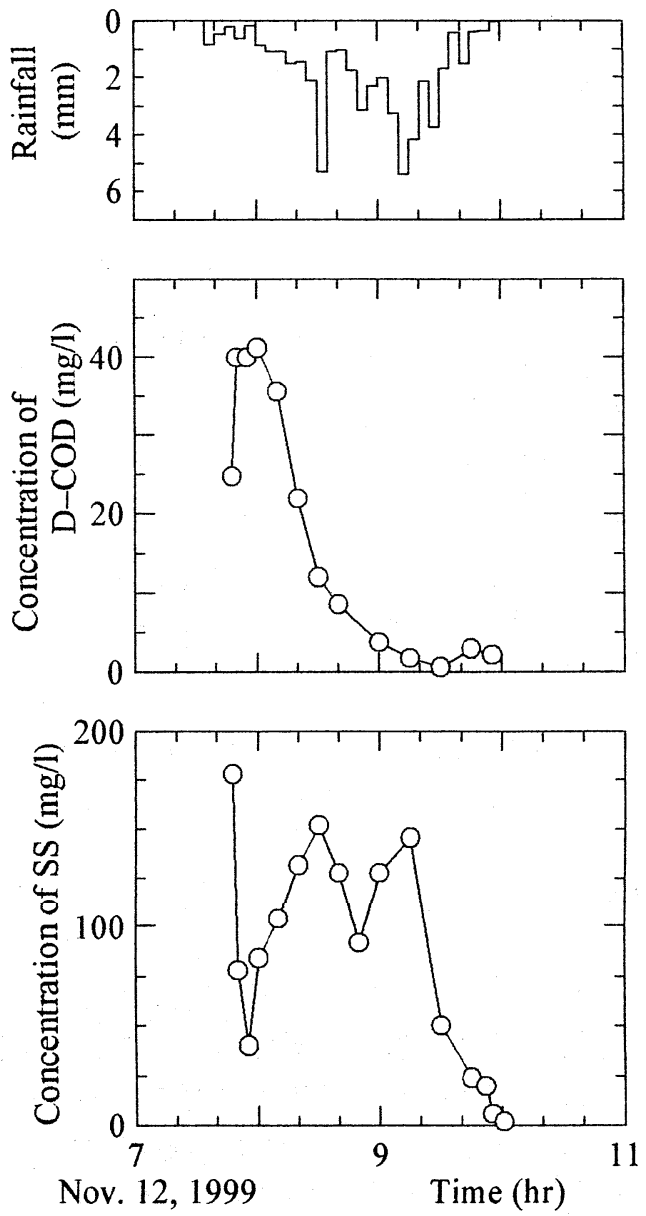

図-8 観測されたポリュート・グラフ (道路面).

を実測結果と対比して, 各出水で共通な $k$ の適値と, 各出水における $P s_{s 0}$ の適值およびこれと前期無降雨日 数との関係を調べた.

污濁負荷流出シミュレーション結果と実測結果を対 比して検討した一例を図-9に示す. また, 前期無降雨 日数と初期堆積污濁負荷量との関係について検討した 結果を図-10に示す.

これらより, はじめに, 道路面における $k$ の適值は, D-COD では $3 \mathrm{~mm}^{-1}$ 程度に, SS では $0.3 \mathrm{~mm}^{-1}$ 程度に なることが確かめられた（図-9 および図-10). 次に, 道路面における $P_{S 0}$ の適值は, D-COD およびSS のい ずれの場合においても, 前期無降雨日数と密接な関係 があり, 図-10 からも明らかなように, 初期堆積污濁 負荷量は前期無降雨日数が増加するにつれて指数関数 的に増大し，やがて一定值に漸近する特性が確かめら れた。なお，前期無降雨日数が 2 週間(14 日) 程度に対 応する初期堆積污濁負荷量は, D-COD では $8.5 \mathrm{mg} / \mathrm{m}^{2}=$ $0.085 \mathrm{~kg} / \mathrm{ha}$ 前後, SS では $420 \mathrm{mg} / \mathrm{m}^{2}=4.2 \mathrm{~kg} / \mathrm{ha}$ 前後 となっている (図-10). 


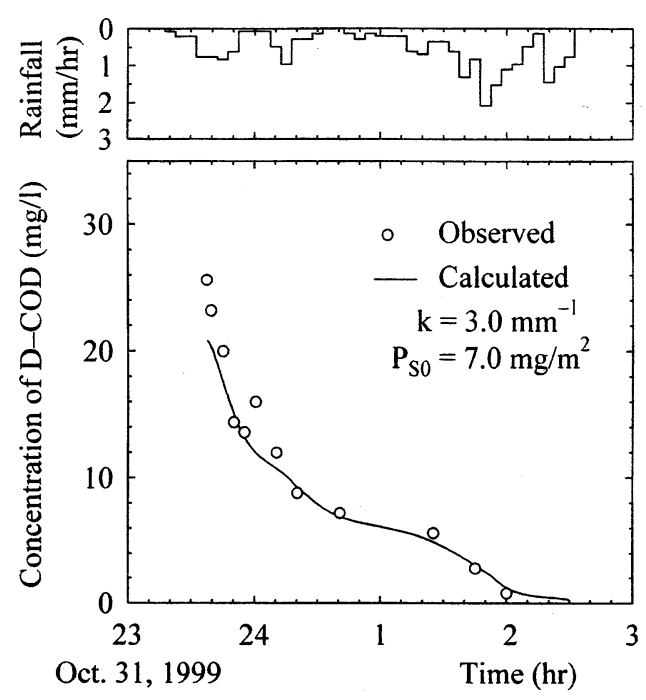

図-9 污濁負荷流出シミュレーション結果 (道路面).

\section{4. 結論}

本研究では, 市街地の屋根面・道路面における雨水・ 污濁負荷流出の観測を行い，既に提案されている流出 面における雨水・污濁負荷流出の基礎式（流出面にお ける雨水・污濁負荷の流出モデル）の適用性ならびに モデル・パラメータの適值について検討を進めた.

以下に，本研究で得られた主要な知見を要約する.

1）市街地の屋根面および道路面における雨水流出は, kinematic wave モデルを用いて精度良く追跡計算 できる.

2) 屋根面および道路面における污濁負荷流出は, 既 に提案されている基礎式(4)および(5)を用いて精度 高くシミュレートし得る.

3）污濁負荷流出量の基礎式(4)における有効降雨のべ キ指数 $b$ は，溶解性の污濁が主体を占める D-COD およびT-COD では $b=1$, 固形性（粒子性）の污濁 が主体を占めるSSおよび濁度では $b>1$ (たとえば, $b=2 ）$ であることが明らかにされた。

4) 污濁負荷流出量の基礎式(4)における污濁負荷流出 係数 $k$ の適值は, 道路面の場合, SS では $0.3 \mathrm{~mm}^{-1}$ 程度, D-COD では $3 \mathrm{~mm}^{-1}$ 程度となることが分かっ た.

5）污濁負荷流出量の基礎式(4)における初期堆積污濁 負荷量 $P_{s 0}$ の適值は, 道路面の場合, 前期無降雨日 数と密接な関係があり, 前期無降雨日数が増加する につれて指数関数的に増大し, やがて一定值に漸近 する特性が確かめられた．また，前期無降雨日数が 2 週間(14日)程度における初期堆積污濁負荷量は, D-COD では $8.5 \mathrm{mg} / \mathrm{m}^{2}=0.085 \mathrm{~kg} / \mathrm{ha}$ 前後, SS で は $420 \mathrm{mg} / \mathrm{m}^{2}=4.2 \mathrm{~kg} / \mathrm{ha}$ 前後となるであろうこと も分かった.

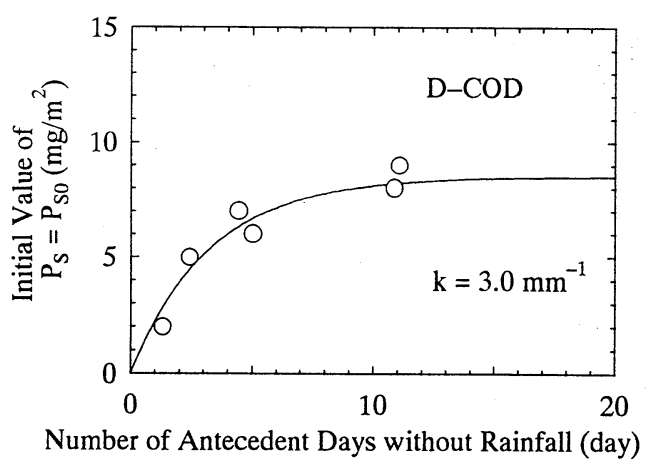

(a) D-COD

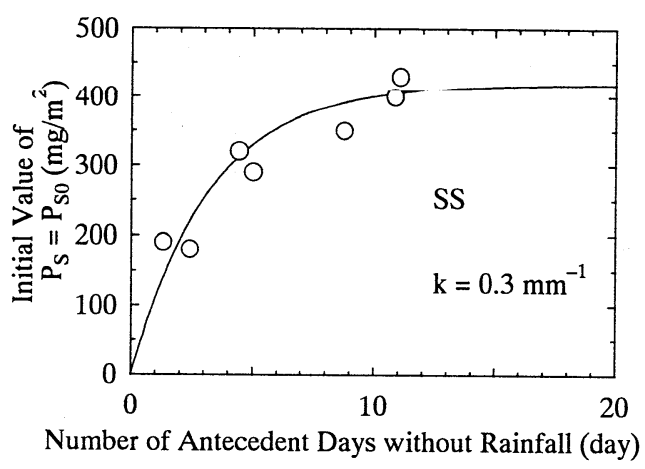

(b) SS

図-10 前期無降雨日数 初期堆積污濁負荷量（道路面).

なお, 本研究の一部は, 平成 12 年度文部省科学研究 費補助金（基盤研究 (C) (2), 研究代表者・渡辺政広) により行われたことを付記する.

\section{参考文献}

1) 渡辺政広・右近雄大・永吉光一: 都市域の屋根面からの污 濁負荷流出特性, 愛媛大学工学部紀要, 第 17 巻, pp. 219 〜227, 1998.

2) 渡辺政広 ・重田尚秀・小林康司 : 市街地の道路面における 雨天時の污濁負荷流出特性，土木学会四国支部第 6 回技術 研究発表会講演概要集, pp. 492 493, 2000.

3) (社)日本下水道協会: 下水試験方法・上巻 -1997 年版-, (社) 日本下水道協会, 1997.

4) Linsley, R. K., Kohler, M. A. and Paulhus, J. L. H.: Applied Hydrology, pp. 268 271, McGraw-Hill, 1949.

5) Huber, W. C. and Dickinson, R. E.: Storm Water Management Model; Ver. 4 - Part A; User's Manual, U. S. EPA/600/3-88/001a, 1988.

6) 渡辺政広 : 都市河川の水質環境, 土木学会 1997 年度（第 33 回）水工学に関する夏期研修会講義集 A コース, pp. A-7-1〜A-7-19, 1997.

（2000.10.2受付） 